\title{
EFEKTIFITAS METODE COACHING DALAM PENDIDIKAN DAN PELATIHAN KEPEMIMPINAN TINGKAT IV ANGKATAN II DAN III DI PUSAT PENGEMBANGAN SUMBER DAYA MANUSIA APARATUR
}

\author{
Ahmad Helmi \\ Pusat Pengembangan Sumber Daya Manusia Aparatur \\ email: helmi@esdm.go.id
}

\begin{abstract}
ABSTRAK
Peraturan Kepala Lembaga Administrasi Negara (LAN) Nomor 13 Tahun 2013 yang telah diubah dengan Peraturan Kepala LAN Nomor 20 Tahun 2015 tentang Pedoman Penyelenggaraan Pendidikan dan Pelatihan (diklat) Kepemimpinan Tingkat IV mengamanatkan pelaksanaan metode pembelajaran selain dari pengajaran mata diklat dalam kelas, berupa: pembimbingan (coaching dan mentoring) dan konseling. Salah satu permasalahan dalam penyelenggaraan Diklat Kepemimpinan Tingkat IV adalah sejauh mana penerapan metode Coaching itu sendiri. Metode Coaching yang kurang efektif dapat menyebabkan peserta didik menjadi kurang termotivasi sehingga output diklat tidak optimal. Ada banyak sekali metode coaching, namun metode seperti apakah yang paling efektif dan efisien untuk digunakan dalam Diklatpim Tingkat IV ini? Penelitian tentang pengaruh metode coaching terhadap Peserta Diklat Kepemimpinan Tingkat IV Angkatan II dan III di Pusat Pengembangan Sumber Daya Manusia Aparatur, Kementerian Energi dan Sumber Daya Mineral (KESDM), dilaksanakan dengan menggunakan pendekatan kuantitatif deskriptif (campuran). Penelitian ini difokuskan pada pengaruh penerapan beberapa metode coaching terhadap peserta Diklat Kepemimpinan Tingkat IV. Hasil penelitian menunjukkan bahwa metode coaching yang dilakukan melalui stimulasi, pertanyaan powerful, dan dialog kreatif mengarahkan peserta didik memperoleh prestasi terbaik seperti yang diharapkan.
\end{abstract}

Kata Kunci: pendidikan dan pelatihan, kepemimpinan tingkat IV, Coaching

\begin{abstract}
Regulation of the Head of National Institute of Public Administration (Lembaga Administrasi Negara: LAN) Number 13 year 2013 as amended by Regulation of the Head of National Institute of Public Administration Number 20 year 2015 on the Guidelines for the Implementation of Education and Training Program on Grade-IV Leadership Management mandates to apply other learning methods in addition to classical method, as: adviser (Coaching and mentoring) and counseling. One of the problems in implementing this education and training program is applying coaching method. Ineffective Coaching method can cause participants to be less motivated and the training output is not optimal. There are many methods of coaching, but what methods are most effective and efficient to apply in this Grade-IV leadership management education and training program? Study on the impact of Coaching methods for effective learning on participants in Education and Training Program on Grade-IV Leadership Management batch II and III year 2018 at the Human Resource Development Center for Apparatus, Ministry of Energy and Mineral Resources (MEMR), was conducted by using a qualitative approach. The discussion in this study is focused on what the effect of several Coaching methods for participants of Education and Training Program on grade-IV Leadership Management. Results show that Coaching is done through stimulation, powerful questions, and creative dialogue so that participants get the best achievement as expected.
\end{abstract}

Kata Kunci: education and training, supervisory leadership management, Coaching

\section{Pendahuluan}

Lembaga Administrasi Negara Republik Indonesia (LAN RI) sebagai pemegang mandat dari pemerintah dalam Pembinaan, penjaminan mutu, dan penyelenggaraan pendidikan dan pelatihan sumber daya aparatur negara terus berupaya melakukan berbagai perubahan guna peningkatan kompetensi dan profesionalisme aparatur negara. Tahun 2012 sampai sekarang melakukan Review Pembaharuan Sistem Diklat Aparatur dengan pendekatan "Adaptive Leadership". Konsep tersebut diadopsi dari konsep Ronald Heifets (2009) yang intinya Kepemimpinan adalah "Kemampuan memobilisasi orang", dan pemimpin harus mampu membedakan antara masalah teknis dan tantangan 

Ahmad Helmi: Efektifitas Metode Coaching Dalam Pendidikan dan Pelatihan Kepemimpinan Tingkat IV Angkatan II Dan III di Pusat Pengembangan Sumber Daya Manusia Aparatur

adaptif (Distinguishing Technical Problem and Adaptive Challenges).

Guna mengoptimalkan konsep tersebut, sesuai dengan Peraturan Kepala Lembaga Administrasi Negara Nomor: 10, 11, 12 dan 13 Tahun 2013 tentang Pedoman Penyelenggaraan Pendidikan dan Pelatihan Kepemimpinan Tingkat I, Tingkat II, Tingkat III dan Tingkat IV (sebagaimana telah dirubah dengan Peraturan Kepala Lembaga Administrasi Negara No. 17, 18, 19 dan 20 Tahun 2015) dalam pelaksanaan kurikulum diklat kepemimpinan saat ini ada kegiatan pembelajaran di luar mata diklat berupa: Pembimbingan (Coaching dan Mentoring) dan Konseling. Coaching dan mentoring ini harus dilakukan dalam proses pelaksanaan Diklat Kepemimpinan karena sesuai dengan amanah dari Perkalan tersebut di atas. Guna membangun pemahaman tentang model Coaching dalam diklat kepemimpinan dan pengembangan teknik Coaching dalam diklat kepemimpinan, penulis merasa perlu untuk melakukan kajian tentang "Efektifitas Metode Coaching dalam Pendidikan dan Pelatihan Kepemimpinan Tingkat IV Angkatan II dan III di Pusat Pengembangan Sumber Daya Manusia Aparatur".

\section{Metode Penelitian}

Penelitian ini adalah penelitian deskriptif kualitatif-kuantitatif (mixed methods) yang menurut Cavaye (1996) dalam suatu penelitian studi kasus dapat menggabungkan dua metode melalui wawancara mendalam, sebuah studi kasus dapat melakukan analisis kualitatif terhadap isu-isu spesifik yang kemudian dapat dijadikan variabel terukur dan selanjutnya dianalisis secara kuantitatif.

Kajian ini dilakukan pada penyelenggaraan Diklatpim Tingkat IV Angkatan II dan III yang diselenggarakan oleh Pusat Pengembangan Sumber Daya Manusia Aparatur, Badan Pengembangan Sumber Daya Manusia, Kementerian ESDM.

Untuk memperoleh data yang diperlukan dalam penelitian ini, penulis menggunakan beberapa metode pengumpulan data yang biasa digunakan dalam sebuah proses penelitian, meliputi observasi, kuesioner, dan wawancara.

Dalam penelitian ini, analisis data yang digunakan adalah analisis deskriptif, yaitu mengungkapkan suatu masalah dan keadaan sebagaimana adanya sehingga hanya merupakan penyingkapan fakta (Warsito, 1992: 10).

Proses analisis data dimulai dengan menelaah seluruh data yang diperoleh baik melalui hasil kuesioner dan bantuan wawancara, kemudian dideskripsikan dengan cara menggunakan analisis persentase. Untuk menghitung persentase jawaban yang diberikan responden, penulis menggunakan rumus seperti yang dikemukakan Hartono (1999) adalah sebagai berikut:

\section{$P=F / N X 100 \%$}

Dimana:

$\mathrm{P}=$ Persentase

$\mathrm{F}=$ Frekuensi yang sedang dicari persentasenya (frekuensi jawaban)

$\mathrm{N}=$ Jumlah responden

Dalam penafsiran data digunakan metode sebagaimana di kemukakan oleh Supardi (1997), yaitu menggunakan dua angka di belakang koma, sebagai berikut:

$$
\begin{array}{ll}
0,00 \% & =\text { Tidak ada } \\
0,01 \%-24,99 \% & =\text { Sebagian kecil } \\
25 \%-49,99 \% & =\text { Hampir setengah } \\
50 \% & =\text { Setengahnya } \\
50,01 \%-74,99 \% & =\text { Sebagian besar } \\
75 \%-99,99 \% & =\text { Pada umumnya } \\
100 \% & =\text { Seluruhnya }
\end{array}
$$

Setelah dibuat persentase, selanjutnya data disajikan dalam bentuk matrik dan diinterpretasikan menggunakan analisis kuantitatif dengan menggunakan metode deduktif dan induktif (mixed methods) sesuai dengan kebutuhan.

\section{Landasan Teori}

Sebelum membahas pentingnya Coaching dan mentoring dalam diklatpim pola baru, terlebih dahulu akan dijelaskan hal-hal yang berkaitan dengan kedua hal tersebut. Definisi Coaching dan mentoring telah banyak disampaikan oleh para pakar. Bresser dan Wilson dalam Passmore (2010) mengutip beberapa pendapat diantaranya;

Coaching adalah kunci pembuka potensi seseorang untuk memaksimalkan kinerjanya. Coaching lebih kepada membantu seseorang untuk belajar daripada mengajarinya. (Whitmore, 2003).

Coaching adalah sebuah proses kolaborasi yang berfokus pada solusi, berorientasi pada hasil, dan sistematis, dimana coach memfasilitasi peningkatan atas performa kerja, pengalaman hidup, pembelajaran diri, dan pertumbuhan pribadi dari coachee. (Grant, 1993). 
Ahmad Helmi: Efektifitas Metode Coaching Dalam Pendidikan dan Pelatihan Kepemimpinan Tingkat IV Angkatan II Dan III di Pusat Pengembangan Sumber Daya Manusia Aparatur

Coaching adalah hubungan profesional antara coach yang berkualitas dengan individu atau kelompok guna mendukung pencapaian hasil yang luar biasa berdasarkan tujuan yang telah ditetapkan oleh individu atau kelompok tersebut. (ICF, 2005).

Coaching adalah seni memfasilitasi kinerja, pembelajaran, dan pengembangan orang lain. (Downey, 2003)

Wilson (2011) menggunakan istilah Coaching kinerja yang diartikan sebagai suatu proses yang memampukan orang untuk menemukan dan bertindak berdasarkan solusisolusi yang paling sesuai dan cocok dengan mereka secara pribadi. Mentoring didefinisikan sebagai orang yang berbagi pengalamannya, pembelajarannya dan nasihatnya kepada mereka yang kurang berpengalaman dalam bidang tertentu. Demikian juga kutipan yang diambil Whitmore (1997) dari buku David Clutterbuck, "Everyone Needs a Mentor", menyatakan bahwa mentoring berasal dari konsep magang, ketika orang yang lebih tua, lebih berpengalaman, mewariskan pengetahuannya tentang bagaimana pekerjaannya dilakukan dan bagaimana beroperasi dalam dunia komersial.

Sedangkan definisi kepemimpinan menurut Ronald Heifets (1995) menyatakan: Leadershipis an activity. Leadership is what individuals do in mobilizing other people, in organizations or communities, to do what I call "adaptive work." (Kepemimpinan adalah kegiatan. Kepemimpinan adalah apa yang seseorang lakukan dalam menggerakkan orang lain, dalam organisasi, komunitas, dan melakukan sesuatu yang disebut "kerja adaptif"). Kerja adaptif dapat berarti mengklarifikasi konflik nilai, atau menjembatani kesenjangan antara nilai-nilai yang kita perjuangkan dan kondisi saat ini di mana kita bekerja. Bila kita memiliki masalah atau tantangan yang tidak ada jawabannya secara teknis, masalah yang tidak bisa dibantu dengan jawaban berdasarkan kewenangan, jawabannya tidak ada disana sehingga masalah tersebut membutuhkan "pekerjaan adaptif". Perbedaan antara keduanya dapatdilihat pada gambar.1 seperti berikut:

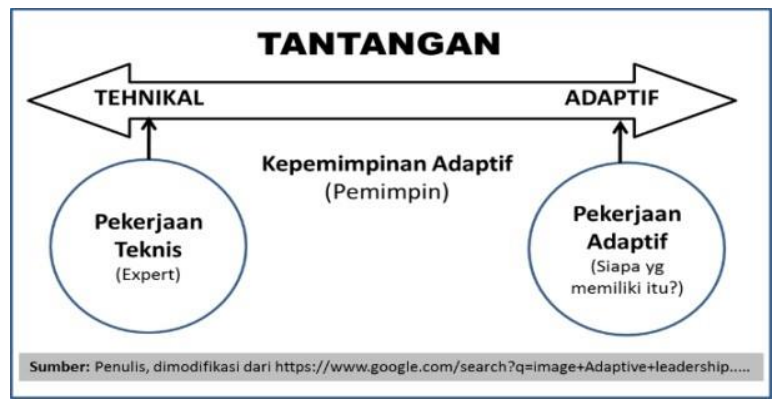

Gambar.1. Perbedaan antara Pekerjaan Teknis dan Pekerjaan Adaptif

Selanjutnya Heifets dkk (2009) dalam bukunya The Practice of ADAPTIVE LEADERSHIP Tools and Tactics for Changing Your Organization and The World, menjelaskan "A successful adaptation enables an organism to thrive in a new and challenging environment" (Keberhasilan beradaptasi mengakibatkan satu organisme dapat hidup dan berkembang dalam lingkungan yang baru dan penuh tantangan). Lebih jauh Heifets menjelaskan bahwa pemimpin perubahan harus mampu membedakan antara masalah teknis (technical problems) dan tantangan adaptif (adaptive challenges). Perbedaan antara masalah adaptif dan hal teknis adalah kunci. Ada masalah yang hanya bersifat teknis (contoh: saya senang ketika seorang mekanik mobil memperbaiki mobil saya, seorang ahli bedah ortopedi memberi kesembuhan kembali tulang saya, atau internis memberi saya penisilin dan menyembuhkan pneumonia saya).

Untuk memahami perbedaan antara masalah teknis dan tantangan adaptif ini, Heifets menjelaskan sebagaimana pada Tabel.1 berikut:

Tabel. 1. Membedakan Masalah Teknis dan Tantangan Adaptif

\begin{tabular}{|l|l|l|l|}
\hline $\begin{array}{c}\text { Jenis } \\
\text { Tantangan }\end{array}$ & $\begin{array}{c}\text { Definisi } \\
\text { Masalah }\end{array}$ & Solusi & Lokus Kerja \\
\hline Teknis & Jelas & Jelas & $\begin{array}{l}\text { Pemegang } \\
\text { Kewenangan }\end{array}$ \\
\hline $\begin{array}{l}\text { Teknis dan } \\
\text { Adaptif }\end{array}$ & Jelas & $\begin{array}{l}\text { Memerlu- } \\
\text { kan } \\
\text { pembela- } \\
\text { jaran }\end{array}$ & $\begin{array}{l}\text { Pemegang } \\
\text { Kewenangan } \\
\text { dan } \\
\text { Pemangku } \\
\text { Kepentingan }\end{array}$ \\
\hline Adaptif & $\begin{array}{l}\text { Memer- } \\
\text { lukan } \\
\text { pembelaja- } \\
\text { ran }\end{array}$ & $\begin{array}{l}\text { Memerlu- } \\
\text { kan } \\
\text { pembela- } \\
\text { jaran }\end{array}$ & $\begin{array}{l}\text { Pemangku } \\
\text { Kepentingan }\end{array}$ \\
\hline $\begin{array}{l}\text { Sumber: Penulis diterjemahkan dari Ronald Heifets } \\
(2009)\end{array}$ & \multicolumn{3}{|l}{} \\
\hline
\end{tabular}


Sejalan dengan konsep Heifets diatas Cem Dener dalam World Bank (2014) menggambarkan hubungan antara technical dan adaptive challenges dalam mewujudkan pemimpin perubahan sebagaimana gambar.2 berikut:

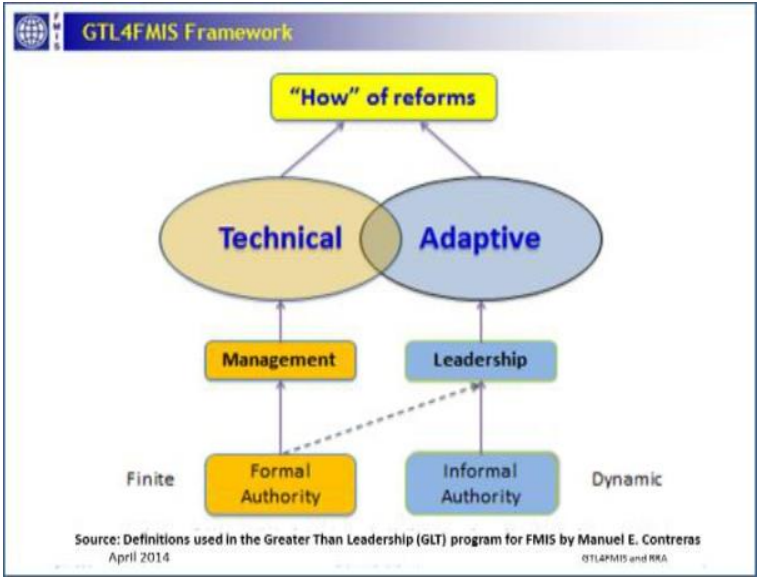

Gambar.2. Leadership Reform

Gambar Leadership Reform menjelaskan bahwa Technical problem adalah berkaitan dengan hal-hal yang bersifat manajemen dan penyelesaiannya ada pada kewenangan formal, sedangkan Adaptive challenges berkaitan dengan kepemimpinan dan hanya dapat diselesaikan melalui pendekatan kewenangan informal.

\section{HASIL DAN PEMBAHASAN}

\section{A. Gambaran Pelaksanaan Coaching dalam Diklatpim Tingkat IV}

1. Mekanisme penunjukan/penetapan coach .

Dari hasil wawancara terhadap para coach PPSDM Aparatur diperoleh informasi bahwa dalam pelaksanaan Coaching selama ini, coach ditunjuk oleh penyelenggara diklatpim dan merupakan penugasan biasa sebagai pembimbing. Dari hasil observasi dan wawancara kepada para coach yang ditugaskan dalam pelaksanaan Diklatpim Tingkat IV angkatan II dan III, Penulis dapat mengidentifikasi adanya lima katagori coach atas dasar indikator: 1). pengalaman jabatan dalam eselon IV, 2). keikutsertaan dalam Diklatpim Tingkat IV, 3). keikutsertaan dalam Sitin Diklatpim Tingkat IV, 4). keikutsertaan dalam Training of Facilitator (Tof) diklatpim tingkat III dan IV, dan 5) mengampu mata diklat pada Diklatpim Tingkat IV. Kategori dan indikator tersebut sebagaimana dapat dilihat pada Tabel.2 berikut ini:
Tabel. 2. Kategori coach pada Diklatpim Tingkat.IV

\begin{tabular}{|c|c|c|c|c|c|}
\hline $\begin{array}{c}\text { Kate- } \\
\text { gori }\end{array}$ & $\begin{array}{c}\text { Pernah } \\
\text { Eselon } \\
\text { IV }\end{array}$ & $\begin{array}{c}\text { Pernah } \\
\text { Mengikuti } \\
\text { Diklatpim } \\
\text { IV }\end{array}$ & $\begin{array}{l}\text { Pernah } \\
\text { Sit-in } \\
\text { Diklat } \\
\text { pim IV }\end{array}$ & $\begin{array}{c}\text { Pernah } \\
\text { TOF } \\
\text { Diklatpim } \\
\text { III dan IV }\end{array}$ & $\begin{array}{c}\text { Mengampu } \\
\text { Mata } \\
\text { Diklat pada } \\
\text { Diklatpim } \\
\text { IV }\end{array}$ \\
\hline I & Ya & Ya & Tidak & Ya & Ya \\
\hline II & Tidak & Tidak & Tidak & Ya & Ya \\
\hline \multicolumn{5}{|l}{ Sumber: Penulis, diolah dari hasil observasi dan wawancara } \\
\hline
\end{tabular}

Dari informasi pada Tabel di atas, kategori coach pada diklatpim tingkat IV dapat dianalisis adanya kesenjangan kompetensi coach yang disebabkan oleh kesenjangan kualifikasi. Hal tersebut akan berpengaruh terhadap kualitas (proses) Coaching yang dilakukan oleh para coach yang ditugaskan dalam Diklatpim Tingkat IV tersebut. Kesenjangan terjadi karena selama ini belum ada panduan yang mengatur dan menetapkan kompetensi dan kualifikasi coach pada Diklatpim Tingkat IV. Berdasarkan uraian sebelumnya, maka dapat dipahami bahwa:

a. Coach pada Diklatpim Tingkat IV saat ini adalah penugasan pembimbingan peserta diklatpim dengan label "coach",

b. Penunjukan coach selama ini belum jelas kompetensi dan kualifikasinya dan akan berpengaruh terhadap kualitas (proses) coaching.

c. Saat ini belum ada panduan yang mengatur dan menetapkan kompetensi dan kualifikasi coach pada Diklatpim Tingkat IV.

\section{Pemahaman aspek-aspek dan praktek Coaching.}

Sebagaimana dijelaskan oleh Atkinson dan Kennedy (2007) dalam bab pendahuluan, bahwa pemahaman akan aspek Coaching menjadi prasyarat utama untuk melakukan Coaching. Hal tersebut menjadi sangat penting karena pemahaman terhadap aspek tersebut akan membedakan dalam praktek antara Coaching dengan yang lainnya seperti: mentoring, counseling, consulting, dan sebagainya. Untuk mengukur tingkat pemahaman terhadap Coaching dari para coach dalam Diklatpim Tingkat IV ini digunakan pengukuran dengan lima aspek, yaitu: Proses, hubungan, struktur, fokus, dan penggunaan alat diagnostik. Dari hasil kajian diperoleh prosentase pemahamam para coach tentang Coaching 
Ahmad Helmi: Efektifitas Metode Coaching Dalam Pendidikan dan Pelatihan Kepemimpinan Tingkat IV Angkatan II Dan III di Pusat Pengembangan Sumber Daya Manusia Aparatur

sebagaimana dapat dilihat pada tabel.3 berikut ini.

Tabel. 3. Prosentase Pemahaman Coach terhadap aspek Coaching

\begin{tabular}{|c|c|c|}
\hline \multicolumn{2}{|c|}{ Pemahaman aspek Coaching } & \multirow{2}{*}{$\begin{array}{l}\begin{array}{l}\text { Prosen- } \\
\text { tase }\end{array} \\
100.0\end{array}$} \\
\hline \multirow[t]{2}{*}{ 1. Proses } & $\begin{array}{l}\text { a. Pada saat proses Coaching: } \\
\text { berusaha memahami pengeta- } \\
\text { huan yang ada pada klien }\end{array}$ & \\
\hline & $\begin{array}{l}\text { b. Pada saat proses Coaching } \\
\text { lebih banyak bertanya: terlibat } \\
\text { untuk mencari tahu dalam } \\
\text { memandu klien }\end{array}$ & 100.0 \\
\hline $\begin{array}{l}\text { 2. Hubu- } \\
\text { ngan }\end{array}$ & $\begin{array}{l}\text { c. Hubungan antara coach dan } \\
\text { klien pada saat Coaching: } \\
\text { cenderung melakukan kemit- } \\
\text { raan }\end{array}$ & 100.0 \\
\hline 3. Struktur & $\begin{array}{l}\text { d. Struktur Coaching yang dila- } \\
\text { kukan selama Diklatpim } \\
\text { Tingkat IV: terstruktur dan } \\
\text { lebih teratur (waktu dijadwal- } \\
\text { kan dan disepakati bersama) }\end{array}$ & 66.67 \\
\hline 4. Fokus & $\begin{array}{l}\text { Fokus perhatian selama } \\
\text { Coaching: } \\
\text { penyelesaian masalah yang } \\
\text { kuat }\end{array}$ & 66.67 \\
\hline $\begin{array}{l}\text { 5. Alat } \\
\text { Diagnos } \\
\text {-tik }\end{array}$ & $\begin{array}{ll}\text { f. Selama Coaching } \\
\text { menggunakan alat diagnostik: } \\
\text { daftar pertanyaan, kuestioner, } \\
\text { lembar observasi, dsb. }\end{array}$ & 33.33 \\
\hline \multicolumn{3}{|c|}{ Sumber: Penulis, diolah dari kuesioner } \\
\hline
\end{tabular}

Tabel 3 menunjukkan bahwa: 1) aspek proses: semua (100.0\%) coach pada saat proses Coaching berusaha memahami pengetahuan yang ada pada klien, dan semua (100.0\%) coach pada saat proses Coaching juga lebih banyak bertanya dan terlibat untuk mencari tahu dalam memandu klien, 2) aspek hubungan: semua (100.0\%) coach pada saat hubungan antara coach dan klien cenderung melakukan kemitraan, 3) aspek struktur: lebih dari setengahnya $(66.67 \%)$ coach melakukan Coaching secara terstruktur (waktu dijadwalkan dan disepakati bersama), 4) aspek fokus: sebagian besar (66.67\%) coach melakukan Coaching dengan fokus perhatian pada membangun penyelesaian masalah yang kuat, 5) aspek penggunaan alat diagnostik: sebagian kecil (33.33\%) coach melakukan Coaching dengan menggunakan alat diagnostik seperti daftar pertanyaan, kuestioner, dan lembar observasi. Dari hasil wawancara dan observasi diperoleh informasi bahwa sebagian besar peserta dan coach belum mendapatkan penjelasan dan pemahaman

tentang aspek-aspek apa saja yang harus diperhatikan dalam praktek Coaching, walaupun ada beberapa coach dan peserta yang berusaha sendiri untuk memahami dan mempelajari tentang Coaching dari berbagai referensi.

Dari Prosentase pemahaman Coach terhadap aspek Coaching dapat diketahui bahwa pemahaman terhadap aspek-aspek Coaching selama ini masih lemah. Baik coach ataupun peserta masih belum semua bisa membedakan antara coaching, mentoring, dan konseling karena sebelum penugasan dan pelaksanaan bimbingan mereka tidak pernah mendapatkan penjelasan dan pengarahan tentang coaching, mentoring, dan counselling secara mendalam, dan mereka baru menjadi coach sejak adanya diklatpim pola baru. Bahkan ada yang baru satu kali menjadi coach. Demikian juga halnya bagi para peserta diklatpim kebanyakan dari mereka baru menjadi klien Coaching sejak mengikuti Diklatpim Tingkat IV.

\section{Keterampilan coach selama proses coaching}

Pemahaman dan keterampilan Coaching bagaikan satu mata uang dengan dua sisi yang berbeda. Keterampilan Coaching adalah sesuatu yang bisa dipelajari namun harus diawali dengan pemahaman tentang Coaching, dan pada akhirnya akan menentukan kualitas Coaching. Sebagaimana dikatakan Marilyn Atkinson (2010): Coaching adalah seni dan ilmu (Coaching is the Art \& Science). Sebagai sebuah ilmu Coaching dapat dipelajari oleh setiap orang. Namun sebagai seni, keterampilan Coaching hanya bisa diperoleh lewat banyak berlatih. Bagaimana gambaran keterampilan dari para coach Diklatpim Tingkat IV saat ini, dapat kita lihat pada tabel berikut ini.

Tabel. 4. Prosentase coach yang memiliki potensi keterampilan Coaching.

\begin{tabular}{|l|c|c|}
\hline \multirow{2}{*}{ Keterampilan Coaching } & \multicolumn{2}{|c|}{ Prosentase Coach } \\
\cline { 2 - 3 } & $\begin{array}{c}\text { Sudah } \\
\text { memiliki } \\
\text { potensi }\end{array}$ & $\begin{array}{c}\text { Belum } \\
\text { memiliki } \\
\text { potensi }\end{array}$ \\
\hline $\begin{array}{l}\text { 1. Coach bertanya hal-hal } \\
\text { yang menginspirasi } \\
\text { terhadap solusi dari } \\
\text { persoalan yang dihadapi } \\
\text { klien. }\end{array}$ & & \\
\hline $\begin{array}{l}\text { 2. Coach bertanya hal-hal } \\
\text { yang memotivasi terhadap } \\
\text { solusi dari persoalan yang } \\
\text { dihadapi klien. }\end{array}$ & & \\
\hline
\end{tabular}




\begin{tabular}{|c|c|c|}
\hline $\begin{array}{l}\text { 3. Coach bertanya hal-hal } \\
\text { yang memprovokasi } \\
\text { terhadap solusi dari } \\
\text { persoalan yang dihadapi } \\
\text { klien. }\end{array}$ & \multirow{5}{*}{$100.0 \%$} & \multirow{5}{*}{$0.0 \%$} \\
\hline $\begin{array}{l}\text { 4.Coach bertanya hal-hal } \\
\text { yang menantang terhadap } \\
\text { solusi dari persoalan yang } \\
\text { dihadapi klien. }\end{array}$ & & \\
\hline $\begin{array}{l}\text { 5.Coach bertanya hal-hal } \\
\text { yang fokusnya kemasa } \\
\text { depan dari persoalan yang } \\
\text { dihadapi klien. }\end{array}$ & & \\
\hline $\begin{array}{l}\text { 6.Coach mendengarkan } \\
\text { jawaban klien dengan } \\
\text { seksama dan berusaha } \\
\text { untuk memahaminya } \\
\text { dengan benar. }\end{array}$ & & \\
\hline $\begin{array}{l}\text { 7.Coach mempertimbangkan, } \\
\text { menguraikan, dan } \\
\text { meringkas setiap jawaban } \\
\text { klien dan memberikan } \\
\text { umpan balik. }\end{array}$ & & \\
\hline \multicolumn{3}{|c|}{ Sumber: Penulis, diolah dari kuesioner } \\
\hline
\end{tabular}

Tabel 4 menunjukkan bahwa semua (100.0\%) coach "sudah memiliki potensi" keterampilan coaching, namun belum dibingkai ke dalam model dan teknis Coaching yang sebenarnya sesuai kaidah Coaching yang semestinya.

Berdasarkan hasil wawancara dan observasi diperoleh informasi bahwa sebagian kecil coach belum mendapatkan pelatihan keterampilan tentang praktik Coaching. Kalaupun ada yang "sudah memiliki potensi" umumnya mereka belajar dan mencari tahu tentang Coaching dari berbagai referensi yang ada, sehingga sering terjadi pada saat proses coaching, yang terjadi adalah mentoring bahkan konseling dilakukan secara bersamaan.

Hasil wawancara dan observasi menunjukkan bahwa sebagian besar coach belum memiliki keterampilan coaching yang semestinya karena mereka belum pernah mendapatkan pelatihan tentang coaching. Umumnya mereka berusaha mempelajari tentang coaching dari berbagai referensi yang ada.

\section{Penggalian kompetensi kepemimpinan adaptif}

Konsep dasar Diklatpim Tingkat IV saat ini adalah kepemimpinan adaptif. Kepemimpinan adaptif ini didefinisikan sebagai proses di mana reformer berusaha untuk memahami dan mempengaruhi perilaku, pola pikir dan nilai-nilai dari berbagai pemangku kepentingan. Oleh karena itu kompetensi coach dalam memahami dan membantu peserta diklatpim untuk menggali halhal yang bersifat adaptif dari persoalan yang dihadapinya menjadi sangat strategis dan menentukan keberhasilan peserta. Bagaimana gambaran kompetensi coach Diklatpim Tingkat IV saat ini dalam menggali hal-hal yang bersifat adaptif dari persoalan yang dihadapi oleh para peserta, dapat dilihat pada tabel.5 berikut.

Tabel 5. Keterampilan coach dalam menggali kompetensi (inovasi) kepemimpinan adaptif.

\begin{tabular}{|c|c|c|}
\hline \multirow[t]{2}{*}{ Keterampilan Coaching } & \multicolumn{2}{|c|}{$\begin{array}{c}\text { Kompetensi } \\
\text { Kepemimpiman } \\
\text { yang Digali dari } \\
\text { Peserta }\end{array}$} \\
\hline & Teknis & Adaptif \\
\hline $\begin{array}{l}\text { 1. Coach bertanya hal-hal yang } \\
\text { menginspirasi terhadap solusi } \\
\text { dari persoalan yang dihadapi }\end{array}$ & \multirow{5}{*}{$0.0 \%$} & \multirow{5}{*}{$100.0 \%$} \\
\hline $\begin{array}{l}\text { 2. Coach bertanya hal-hal yang } \\
\text { memotivasi terhadap solusi } \\
\text { dari persoalan yang dihadapi }\end{array}$ & & \\
\hline $\begin{array}{l}\text { 3. Coach bertanya hal-hal yang } \\
\text { memprovokasi terhadap solusi } \\
\text { dari persoalan yang dihadapi }\end{array}$ & & \\
\hline $\begin{array}{l}\text { 4. Coach bertanya hal-hal yang } \\
\text { menantang terhadap solusi dari } \\
\text { persoalan yang dihadapi }\end{array}$ & & \\
\hline $\begin{array}{l}\text { 5. Coach bertanya hal-hal yang } \\
\text { fokusnya kemasa depan dari } \\
\text { persoalan yang dihadapi }\end{array}$ & & \\
\hline
\end{tabular}

Dari tabel Keterampilan coach dalam menggali kompetensi (inovasi) kepemimpinan adaptif di atas dapat diketahui bahwa semua coach (100.0\%) sudah memiliki potensi keterampilan coaching dengan melakukan penggalian kompetensi peserta yang bersifat adaptif. Dari hasil wawancara dan observasi diperoleh jawaban masih ada coach dan peserta yang belum memahami dengan jelas perbedaan antara persoalan teknis (tehnical problems) dan tantangan adaptif (adaptive challenges). Kekurangfahaman tersebut karena selama ini mereka kurang mendapat penjelasan dan pelatihan bagaimana membedakan antara masalah teknis dan tantangan adaptif yang selaras dengan inovasi pada level dan scoping Diklatpim Tingkat IV. 
Ahmad Helmi: Efektifitas Metode Coaching Dalam Pendidikan dan Pelatihan Kepemimpinan Tingkat IV Angkatan II Dan III di Pusat Pengembangan Sumber Daya Manusia Aparatur

\section{B. Pengembangan Model Coaching dalam Diklatpim Tingkat IV.}

Berdasarkan hasil kajian, sampai saat ini belum ada model dan teknis Coaching yang dijadikan acuan dalam pelaksanaan Coaching pada Diklatpim Tingkat IV, karena sampai saat ini Lembaga Administrasi Negara ataupun Pusat Pengembangan Sumber Daya Manusia Aparatur belum menerbitkan panduan yang mengatur tentang model dan teknis Coaching pada Diklatpim Tingkat IV. Untuk menyiapkan model dan teknis Coaching yang tepat dengan peningkatan kompetensi kepemimpinan (adaptif) peserta Diklatpim Tingkat IV, beberapa model dan alat/instrumen akan dikaji agar dapat dijadikan sebagai prototipe: "model dan teknis Coaching pada Diklatpim Tingkat IV", diantaranya adalah sebagai berikut.

\section{Alternatif Model Coaching Alternatif-1: Model GROW (Coaching Model Ideal).}

Sebagaimana dijelaskan oleh Carter (2006) pada bab pendahuluan Coaching sebagai alat yang efektif dalam peningkatan kapasitas pegawai dalam organisasi dapat dilakukan dengan menggunakan tiga pendekatan, yaitu:

1) Menggunakan Coach-Specialist dari dalam organisasi,

2) Menciptakan Budaya Coaching gaya manajemen (dikenal sebagai: atasan sebagai coach), dan

3) Menggunakan Eksekutif-Coach dari luar organisasi.

Merujuk pada ketiga pendekatan tersebut, keberadaan coach pada Diklatpim Tingkat IV lebih mendekati Coaching dalam organisasi dengan menggunakan "eksekutif coach dari luar organisasi". Sebagai coach dari luar organisasi maka hubungan antara coach dan peserta diklatpim bukan hubungan antara atasan dan bawahan dan bukan juga sebagai rekan kerja. Oleh karena itu sebagai eksekutif-coach dari luar organisasi maka posisi coach dalam Diklatpim Tingkat IV harus benar-benar coach as a coach, dalam artian coach harus benar-benar sebagai profesional coach (Great Coach). Alternatif untuk keperluan tersebut, nampaknya GROW dapat menjadi model yang cukup efektif untuk digunakan.

Sebagaimana dijelaskan oleh Dembkowski and Eldridge (2003) dalam pendahuluan, model GROW merupakan satu model Coaching kinerja yang pertama kali dikembangkan dan terus berkembang menjadi yang paling popular. Ini adalah kerangka kerja yang sederhana namun kuat untuk memandu sesi coaching. Coach mengajukan serangkaian pertanyaan yang berkaitan dengan Goal (tujuan) seseorang/organisasi, Reality (realitas) mereka/organisasi, Options (Pilihan-pilihan) seseorang/organisasi, dan Will (keinginan) seseorang/organisasi.

GROW : Bekerja dari luar ke dalam. G adalah tujuan akhir, inspirasi dan disertai dengan tujuan kinerja yang ada di dalam jangkauan pengaruh klien. $\mathbf{R}$ adalah realitas (obyektif dan spesifik), $\mathbf{O}$ adalah untuk sasaran (terukur dan spesifik), $\mathbf{W}$ adalah untuk jalan ke depan (rencana aksi dan garis waktu). Pendekatan GROW menuntut keterampilan, kualitas dan pola pikir (mind-set) coach sebagai coach, yaitu:

1) Keterampilan: coach harus mampu:

a. Mendengarkan untuk memahami.

b. Bertanya yang menimbulkan kesadaran

c. Penguasaan diri

d. Pemahaman struktur

e. Membangun hubungan (komunikasi)

f. Mengamati hubungan pola pikir dan perilaku klien

g. Memberikan umpan balik

h. Melakukan tahap pengembangan dan kredibilitas

i. Meningkatkan keterampilan

2) Kualitas coach: sikap coach terhadap klien harus:

a. Perhatian/Respek

b. Intuisi

c. Tulus

d. Terpercaya dan dapat dipercaya

e. Bijaksana

f. Berkomitmen dan mendukung

g. Optimis

h. Jujur

i. Model peran yang baik

j. Transparan

k. Sabar

1. Mandiri

3) Pola pikir (Mindset): pikiran-sikap-tindakan coach terhadap klien, lingkungan, dan dirinya sendiri.

Pola pikir adalah bingkai yang lebih besar dari pikiran di mana kualitas dan keterampilan dapat beroperasi :

1) Semua orang memiliki dalam diri mereka potensi yang sangat besar

2) Kita masing-masing memiliki pandangan yang 
Ahmad Helmi: Efektifitas Metode Coaching Dalam Pendidikan dan Pelatihan Kepemimpinan Tingkat IV Angkatan II Dan III di Pusat Pengembangan Sumber Daya Manusia Aparatur

unik tentang realitas

3) Orang-orang pada dasarnya baik

4) Kita masing-masing bertanggung jawab atas hasil yang kita dapatkan dalam hidup

5) Selalu berniat baik

Model GROW adalah kerangka kerja yang sederhana namun kuat untuk memandu sesi coaching. Coach mengajukan serangkaian pertanyaan yang berkaitan dengan Goal (tujuan) organisasi peserta diklatpim, Reality (realitas) organisasi peserta diklatpim, Options (Pilihanpilihan) organisasi peserta diklatpim, dan Will (keinginan) organisasi peserta diklatpim.

\section{Implementasi Coaching Model GROW:}

G - Goal. Pada sesi awal klien (peserta diklatpim) harus mempunyai tujuan yang jelas. Tujuan organisasi sedapat mungkin harus spesifik dan terukur, memungkinkan coach untuk bertanya: Bagaimana anda akan tahu bahwa anda telah mencapai tujuan itu? Apa harapan dari orang lain terhadap anda ? Siapa lagi yang perlu tahu tentang rencana anda? Bagaimana anda akan memberitahu mereka? Dan seterusnya.

$\mathrm{R}$ - Reality. Klien harus mengetahui realitas saat ini dan tahu dari mana akan memulainya. Hal ini menjadi sesi terpenting dalam sesi Coaching. Situasi saat ini dari organisasi yang mengalami tersebut membutuhkan analisis yang cermat. Kadang-kadang, hanya dengan melihat situasi dengan jelas (bukan apa yang dibayangkan), resolusinya menjadi jelas. Coach dapat bertanya: Selama ini apa yang menyebabkan anda berhenti untuk mencapai tujuan anda? Apakah anda tahu siapa saja yang telah mencapai tujuan itu? Apa yang dapat anda pelajari dari mereka? Dan seterusnya.

O - Options. Setelah klien tahu di mana dia/organisasinya berada dan ke mana organisasinya ingin menuju, langkah berikutnya adalah untuk mengeksplorasi pilihan yang klien miliki untuk menuju ke sana. coach dapat bertanya:Apa yang bisa anda lakukan sebagai langkahpertama? Apa lagi yang bisa anda lakukan? Apa yang akan terjadi jika anda tidak melakukan apa pun? Dan seterusnya.

W - Will. Untuk mengubah dan meningkatkan kinerja, motivasi sangat diperlukan. Hasil yang diinginkan dari tahap ini adalah komitmen untuk bertindak. Pertanyaan-pertanyaan berikut dapat memandu coach: Tujuan yang mana cocok dengan prioritas jabatan anda saat ini? Hambatan apa yang mungkin akan anda temui? Bagaimana anda akan mengatasinya? Seberapa besar komitmen anda untuk tujuan ini? Langkah-langkah apa yang perlu anda ambil untuk mencapai hal ini? Dan seterusnya. Secara lebih rinci tahapan/ prosesnya dapat dilihat seperti gambar. 3 .

Model ini sangat tepat digunakan dalam diklat kepemimpinan tingkat IV mengingat setiap peserta diklat yang merupakan pemimpin pada unit kerjanya pasti memiliki tujuan organisasi, realitas organisasi saat ini, pilihan-pilihan untuk mencapai tujuan organisasi, dan keinginan/ komitmen untuk mewujudkannya.

\section{Empat langkah coaching model Grow}

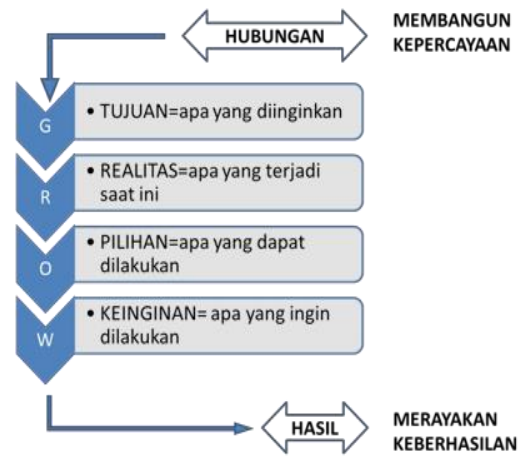

Gambar. 3. Empat langkah Coaching model GROW

\section{Alternatif-2: Model Coach-Mentor Continuum (Model campuran).}

Peserta diklat kepemimpinan tingkat IV adalah mereka yang sudah duduk dalam jabatan eselon IV. Keragaman peserta diklat dari aspek: level jabatan, lama jabatan, level pendidikan, asal instansi, asal daerah, usia, dan sebagainya, berdampak kepada pengalaman, lingkup kendali, kemampuan, dan motivasi peserta dalam mengikuti diklat kepemimpinan. Demikian juga halnya dengan dengan coach dalam Diklatpim Tingkat IV memiliki keragaman berupa: 1). Pengalaman dan lama jabatan dalam eselon IV, 2). Keikutsertaan dalam Diklatpim Tingkat IV, 3). Keikutsertaan dalam Sit-in diklatpim tk.III dan IV, 4). Keikutsertaan dalam Tof Diklatpim Tingkat IV, dan 5) Mengampu mata diklat pada Diklatpim Tingkat IV, dan sebagainya. Keragaman peserta dan keragaman coach dalam Diklatpim Tingkat IV akan sangat berpengaruh terhadap proses dan keberhasilan Coaching. Untuk itu perlu dirancang alternatif model Coaching yang tepat (sesuai dengan situasi dan 
Ahmad Helmi: Efektifitas Metode Coaching Dalam Pendidikan dan Pelatihan Kepemimpinan Tingkat IV Angkatan II Dan III di Pusat Pengembangan Sumber Daya Manusia Aparatur

kondisi tersebut) untuk digunakan dalam penyelenggaraan Diklatpim Tingkat IV.

Sejalan dengan situasi dan kondisi sebagaimana dijelaskan oleh Clutterbuck in Hobson (2003): "Coaching often slides into Mentoring" (Coaching selalu bergeser ke mentoring ketika diskusi dan dialog yang dilakukan melebar ke masalah yang lebih luas, sehingga diharapkan pada saat melakukan coching, seorang coach harus fokus pada tujuan). Oleh karena itu pendekatan yang tepat akan efektif pada saat yang tepat. Jadi pendekatan efektif akan berbeda dalam situasi yang berbeda. Oleh karena itu coach sebaiknya kompeten di kedua gaya tersebut, sehingga memungkinkan keduanya digunakan sebagai suatu cara yang tepat pada waktu yang tepat. Hubungan antara coach dan mentor secara kontinuum dapat dilihat secara direktif - non direktif sebagaimana gambar 4 berikut ini.

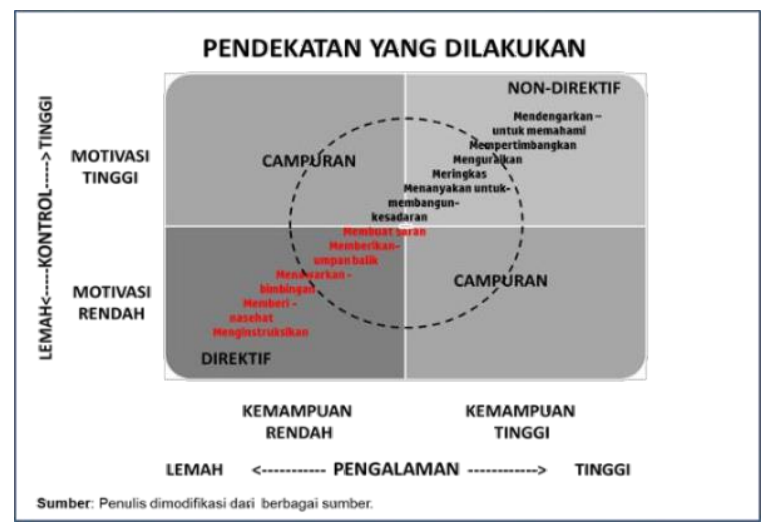

Gambar 4. Model pendekatan CoachMentor Continum dalam Diklatpim Tingkat IV.

Gambar Model pendekatan Coach-Mentor Continum dalam Diklatpim Tingkat IV dapat disimulasikan: pada saat peserta diklat memiliki kemampuan rendah dalam kompetensi atau perilaku tertentu, memiliki motivasi rendah untuk berbuat, pengalaman jabatan yang lemah, dan kemampuan mengendalikan (otoritas) rendah, menggunakan pendekatan direktif memiliki potensi yang tinggi untuk keberhasilan. Pada kondisi tersebut keterampilan Coaching tetap masih diperlukan, dan mengarah ke direktif dapat mencapai hasil yang lebih baik. Sejalan dengan meningkatnya kemampuan, motivasi, pengalaman, dan pengendalian yang dimiliki peserta, coach mempunyai peluang untuk memilih pendekatan campuran/blended (pada batas lingkaran). Ketika kemampuan, motivasi, pengalaman, dan pengendalian yang dimiliki peserta tinggi, coach dapat melakukan pendekatan nondirektif Coaching untuk mencapai hasil terbaik.

Dalam hubungan atasan-bawahan di tempat kerja, pendekatan direktif coaching berdasarkan sifatnya mempertahankan beberapa tingkatan tanggung jawab atas hasil keputusan dan perilaku bawahan. Apapun keputusan dan kegiatan yang dilakukan oleh bawahan dari hasil Coaching, tanggung jawabnya tetap ada pada atasan. Jadi, ketika coach memberikan arahan tertentu, atau keputusan berkenaan dengan keterampilan dan perilaku, maka tanggung jawabnya kembali kepada coach jika hal tersebut tidak berhasil, artinya ada pergeseran akuntabilitas. Non-direktif Coaching aman dari ikatan tanggung jawab dan akuntabilitas antara coach dan peserta, karena sejak dari awal peserta membuat keputusan dan menentukan arahnya sendiri.

Oleh karena itu Coach harus mampu memilih dan menetapkan secara tepat salah satu gaya intervensi tersebut, apakah gaya direktif Coaching, blended Coaching (campuran), atau non-direktif Coaching. Untuk mempermudah coach memutuskan gaya mana yang paling tepat dari intervensi tersebut, selain coach harus terampil dalam mencermati kemampuan, motivasi, pengalaman, dan pengendalian yang dimiliki peserta, disarankan untuk menggunakan pendekatan CORE - yaitu:

Context $=$ memahami konteks permasalahan peserta,

Objectives of the clients $=$ memahami tujuan peserta,

Relationships with others = memahami hubungan antara kondisi saat ini dan keinginan peserta,

Experiences $=$ memahami pengalaman peserta Dalam perspektif Diklatpim Tingkat IV, disarankan sebaiknya coach "boleh turun" hanya sampai pada pendekatan campuran (dalam batas lingkaran), karena dapat diasumsikan jika menggunakan pendekatan direktif peserta Diklatpim Tingkat IV tersebut tidak punya kapasitas dan tidak layak untuk menjadi pemimpin strategis.

Sebelum menggunakan pendekatan campuran, semaksimal mungkin coach menggunakan pendekatan non-direktif Coaching. Dengan kata lain pendekatan campuran hanya digunakan jika memang sangat diperlukan karena kemampuan,

motivasi, pengalaman, dan pengendalian yang dimiliki peserta rendah.

Dikaitkan dengan adaptive leadership, metode coach-mentor kontinum ini sangat tepat 
Ahmad Helmi: Efektifitas Metode Coaching Dalam Pendidikan dan Pelatihan Kepemimpinan Tingkat IV Angkatan II Dan III di Pusat Pengembangan Sumber Daya Manusia Aparatur

untuk digunakan antara lain karena:

Pendekatan direktif Coaching bisa digunakan di luar sesi Coaching untuk penegasan dan mengingatkan kepada peserta berkaitan dengan hal-hal yang bersifat teknikal/formal authority yang merupakan "keharusan/ kewajiban" yang harus dilakukan oleh peserta sebagai pemegang tanggung jawab formal sesuai jabatannya.

Pendekatan non-direktif Coaching bisa digunakan untuk pendalaman yang berkaitan dengan hal-hal yang bersifat adaptif/informal authority yang merupakan kemampuan kepemimpinan yang harus dikembangkan oleh setiap peserta sesuai jenjang jabatan yang akan/sudah didudukinya.

Memperhatikan keberagaman peserta dan coach pada diklat kepemimpinan tingkat IV, nampaknya metode direktif-non-direktif Coaching (Coach-Mentor Continuum) ini sangat tepat untuk digunakan dalam diklat kepemimpinan. Dengan pendekatan tersebut, coach lebih fleksibel melakukan pergeseran gaya/ pendekatan dari non-directive ke directive atau sebaliknya sesuai kebutuhan.

Kedua model tersebut akan sangat relevan untuk mengeksplorasi kompetensi kepemimpinan para peserta diklatpim. Dari dua alternatif model tersebut, model alternatif 2 (Coach-Mentor Continuum) akan lebih akomodatif terhadap situasi dan kondisi Diklatpim Tingkat IV saat ini. Penggunakan model 2 tetap berasosiasi dengan model 1 karena keterampilan Coaching masih tetap diperlukan. Selain itu model coach-mentor kontinum lebih fleksibel dan bisa menjadi media pembelajaran yang kuat untuk menjadi coach yang sebenarnya (Coach as a coach=Great Coach).

\section{Alternatif alat (tools)}

a. Logical Level Alignment (LLA).

Selain sebagai Coaching frameworkdan proses Coaching, Logical Level Alignment juga sebuah alat dalam Coaching. Manfaat keselarasan antara logical level dengan hierarki suatu organisasi.

Pengetahuan tentang logical levels memung-

kinkan orang untuk mengarahkan kehidupan mereka. Seseorang pada tingkat yang lebih tinggi memegang kendali atas individu atau organisasi dalam mengembangkan visi, tujuan, misi, identitas, inspirasi, pilihan, dan motivasi.

Alat/instrumen ini sangat tepat digunakan dalam diklat kepemimpinan mengingat dalam diklat kepemimpinan juga ada penjenjangan tingkat I sampai tingkat IV, dan masing-masing level juga memiliki lingkup kerja (scoping). Selaras dengan itu fokus pencermatan coach dengan menggunakan LLA dapat disesuaikan dengan level diklat kepemimpinan sebagai berikut:

1) Level Identity = dapat digunakan dalam pencermatan/meng-eksplore tantangan adaptif pada level Diklatpim Tk I.

2) Level Values/Belief = dapat digunakan dalam pencermatan/ mengeksplor tantangan adaptif pada level Diklatpim Tk II.

3) Level Capability = dapat digunakan dalam pencermatan/mengeksplor tantangan adaptif pada level Diklatpim Tk III.

4) Level Action/Behavior $=$ dapat digunakan dalam pencermatan/mengeksplore tantangan adaptif pada level Diklatpim Tk IV.

Dengan menggunakan LLA sangat dimungkinkan bagi coach untuk membawa pemikiran hasil inovasi peserta ke level/scope diklatpim yang diikutinya. Misal pada saat peserta menyusun proyek perubahan memasukkan hasil inovasinya tidak sesuai dengan level jabatannya, mungkin terlalu tinggi atau terlalu rendah dari level diklat kepemimpinan yang sedang diikutinya, maka coach bisa melakukan Coaching dengan teknis "Pull-up" (menarik ke atas) atau teknis "Pull-down" (menarik ke bawah) sampai ke level jabatan yang semestinya.

\section{b. Outcome Frame}

Komunikasi tanpa hasil bagaikan bepergian tanpa tujuan. Sebagai coach kita gunakan Outcome frame untuk mengevaluasi apakah klien kita pada jalur yang benar dan mengambil tindakan dengan langkah yang diperlukan untuk mencapai tujuannya.

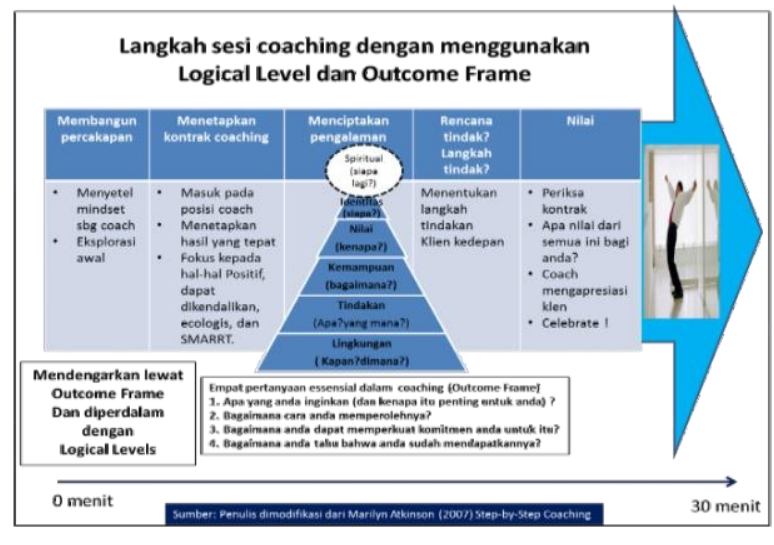

Gambar. 5. Langkah Coaching dengan menggunakan Logical Level dan Outcome Frame 
Ahmad Helmi: Efektifitas Metode Coaching Dalam Pendidikan dan Pelatihan Kepemimpinan Tingkat IV Angkatan II Dan III di Pusat Pengembangan Sumber Daya Manusia Aparatur

Logical Level Alignment dan Outcome Frame merupakan alat/instrument yang sangat sederhana dalam coaching tapi cukup kuat untuk menggali inovasi dan kompetensi kepemimpinan (adaptif) peserta Diklatpim Tingkat IV. Prosesnya terutama pada langkah 4 (menyusun rencana aksi/ langkah aksi) sangat membantu para peserta diklat dalam menetapkan milestone pada penyusunan Rancangan Proyek Perubahan. Prosesnya yang sederhana dan fleksibel dimungkinkan untuk digunakan pada setiap level diklatpim.

\section{Kesimpulan}

Coaching adalah kegiatan integratif dalam pelaksanaan Diklatpim Tingkat IV. Bersamasama dengan mentoring, konseling, dan unsur lainnya akan sangat berpengaruh terhadap pencapaian mutu pelatihan peserta diklatpim. Dalam pelaksanaannya saat ini proses Coaching dalam Diklatpim Tingkat IV terkendala oleh beberapa keterbatasan, seperti: 1. Mekanisme penunjukan coach yang belum jelas kompetensi dan kualifikasinya, 2. Pemahaman coach terhadap aspek-aspek dan praktek Coaching yang masih lemah, 3. Keterampilan coach selama Coaching proses yang masih lemah, dan 4. Penggalian kompetensi kepemimpinan adaptif yang belum sesuai dengan konsep diklatpim yang ditelah ditetapkan.

Dari kajian "Evaluasi Dan Pengembangan

Model Coaching Pada Pendidikan Dan Pelatihan Kepemimpinan Tingkat IV Di Pusat Pengembangan Sumber Daya Manusia Aparatur" hasilnya diuraikan pada simpulan dan diikuti dengan rekomendasi sebagai berikut:

1. Penunjukan coach pada Diklatpim Tingkat IV selama ini adalah penugasan pembimbingan peserta diklatpim dengan label "coach". Penunjukan coach belum didasari atas kejelasan kompetensi dan kualifikasi, karena selama ini belum ada panduan yang mengatur dan menetapkan kompetensi dan kualifikasi coach pada Diklatpim Tingkat IV.

2. Pemahaman dan praktek Coaching oleh para coach dalam Diklatpim Tingkat IV selama ini belum sesuai dengan yang semestinya, dikarenakan sebelum penugasan mereka tidak pernah mendapatkan penjelasan dan pengarahan tentang Coaching, dan mereka baru menjadi coach sejak adanya diklatpim pola baru, bahkan ada coach yang baru tahun 2017 ini mengampu sebagai coach.

3. Sebagian coach "belum memiliki potensi" keterampilan Coaching, sedangkan sebagian dari "mereka yang sudah punya potensi keterampilan" umumnya mereka memahami dan mempelajari sendiri tentang Coaching dari berbagai referensi.

4. Semua coach sudah menggali kompetensi kepemimpinan adaptif dari para peserta sebagaimana semestinya, tetapi dalam pelaksanaannya belum seluruhnya dilakukan dikarenakan mereka belum memahami dengan jelas dan masih terjadinya persepsi yang berbeda-beda tentang persoalan teknis (tehnical problems) dan tantangan adaptif (adaptive challenges). Hal itu terjadi karena selama ini mereka kurang mendapat penjelasan dan pelatihan bagaimana membedakan antara masalah teknis dan tantangan adaptif yang selaras dengan inovasi pada level dan scoping Diklatpim Tingkat IV.

5. Model alternatif Coach-Mentor Continuum lebih akomodatif terhadap situasi dan kondisi Diklatpim Tingkat IV saat ini, selain itu model coach-mentor continuum lebih fleksibel dan bisa menjadi media pembelajaran yang kuat untuk menjadi Coaching yang sebenarnya (Coach as a coach=Great Coach).

6. Logical Level Alignment dan Outcome Frame merupakan alat/instrument yang sangat sederhana dalam Coaching tapi cukup kuat untuk menggali inovasi dan meningkatkan kompetensi kepemimpinan (adaptif) peserta pada Diklatpim Tingkat IV. Selain sederhana juga fleksibel dan dimungkinkan untuk digunakan pada setiap jenjang diklatpim.

Rekomendasi yang dapat disampaikan sebagai berikut:

1. Untuk mengoptimalkan proses Coaching sebagai media dalam membekali, memotivasi, dan menggali kompetensi kepemimpinan peserta Diklatpim Tingkat IV perlu segera ditetapkan panduan yang di dalamnya mengatur syarat/standar kompetensi dan kualifikasi coach pada Diklatpim Tingkat IV.

2. Untuk meningkatkan pemahaman dan keterampilan para coach dalam praktek coaching pada Diklatpim Tingkat IV perlu segera diadakan pelatihan, penjelasan dan pengarahan tentang Coaching sebelum mereka ditugaskan sebagai coach pada Diklatpim Tingkat IV.

3. Untuk meningkatkan pemahaman dan penyamaan persepsi serta kapasitas/kompetensi para coach dalam menggali potensi kepemimpinan adaptif peserta Diklatpim Tingkat IV, perlu segera diadakan pelatihan/workshop/ 
Ahmad Helmi: Efektifitas Metode Coaching Dalam Pendidikan dan Pelatihan Kepemimpinan Tingkat IV Angkatan II Dan III di Pusat Pengembangan Sumber Daya Manusia Aparatur

lokakarya yang dapat meningkatkan pemahaman coach dan peserta dalam membedakan masalah teknis dan tantangan adaptif yang selaras dengan inovasi pada level dan scoping Diklatpim Tingkat IV.

4. Untuk menyiapkan model dan teknik Coaching yang sederhana, fleksibel dan sangat kuat untuk meningkatkan kompetensi kepemimpinan (adaptif) peserta Diklatpim Tingkat IV, model Coaching: Coach-Mentor Continuum dan alat/instumen Logical Level Alignment dan Outcome Frame dapat dijadikan prototipe sebagai model dan teknik Coaching pada Diklatpim Tingkat IV.

5. Untuk memaksimalkan peran dan fungsi: coach, mentor, dan konselor pada Diklatpim Tingkat IV perlu segera ditetapkan pedoman yang mempertegas tentang Coaching, mentoring, dan konseling, dan diselenggarakan pelatihan Coaching, Mentoring, dan Konseling.

\section{REFERENSI}

Alison Carter (2006), Practical Methods for Evaluating Coaching, Institute For Employment Studies Mantell Building University Of Sussex Campus Falmer Brighton BN1 9RF UK.

Bungin, Burhan. 2009 Penelitian Kualitatif. Jakarta : Kencana. 2006 Sosiologi Komunikasi. Jakarta : Kencana

Cavaye, A.L.M. (1996). Case study research: a multi- faceted research approach for IS. Information systems journal 6(3): 227242.

Cem Dener (2014) GTL4FMIS, Greater Than Leadership Program for Financial Management Information Systems: Adaptive Leadership program for FMIS Development, Governance and Public Sector Management (PRMPS) Practice Poverty Reduction and Economic Management (PREM) Network The World Bank, April 2014

Clutterbuck, David. 1998. Learning Alliances: Tapping Into Talent. Chartered Institute of Personnel and Development.

Dembowski and Fiona, 2003. The Achieve Coaching Model ${ }^{\circledR}$ - A Systematic Approach to Greater Eff ectiveness in Executive Coaching

Fran Deans and Louise Oakley with Rick James and Rebecca Wrigley (2006), Coaching and Mentoring for Leadership
Development in Civil Society, Praxis Paper No. 14 January 2006

Heifets R, Grashow A, Linsky M (2009), The Practice of ADAPTIVE LEADERSHIP Tools and Tactics for Changing Your Organization and The World, Cambridge Leadership Associates

Karl Inge Tangen (2011), Integrating Life Coaching And Practical Theology Without Losing Our Theological Integrity, Journal of Biblical Perspectives in Leadership 3, no. 1 (Winter 2010), 13-32. (C) 2011 School of Global Leadership \& Entrepreneurship, Regent University ISSN 1941-4692

Kountur, Ronny. 2007. Metode Penelitian Untuk Penulisan Skripsi dan Tesis. Edisi Revisi. Jakarta: PPM.

Lauron Buys (2007) Management by Coaching: 7 Basic Keys Paperback - September 1, 2007

Logan D and King John (2004) The Coaching Revolution: How Visionary Managers Are Using Coaching to Empower People and Unlock Their Full Potential.

Marilyn Atkinson, PhD, Rae T. Chois, (2007) Inner Dynamic of Coaching, Art \& Science of Coaching series

Marilyn Atkinson, PhD, Rae T. Chois, (2010) Step-by-Step Coaching, Art \& Science of Coaching series

Modul I-IV, The Art and Science Of Coaching, Erickson International, 2010

MTD Training (2010) Coaching and Mentoring, MTD Training \& Ventus Publishing ApS, ISBN 978-87-7681595-0

Passmore, J. 2010. Excellence in Coaching Panduan Lengkap Menjadi Coach Profesional. Edisi Terjemahan. Penerbit PPM, Jakarta

Warsito, Hermawan. 1992.Pengantar Metodologi Penelitian. Jakarta: Gramedia Pustaka Utama

Whitmore, J. 1997. Coaching for Performance Seni Mengarahkan untuk Mendongkrak Kinerja. Edisi Terjemahan. Penerbit PT Gramedia Pustaka Utama, Jakarta.

Wilson, C. 2011. Performance Coaching Metode Baru Mendongkrak Kinerja Karyawan. Edisi terjemahan. Penerbit PPM, Jakarta.

Hartono, Jogiyanto. 1999. Analisis Dan Disain Sistem Informasi: pendekatan terstruktur teori dan praktek aplikasi bisnis

Hobson, A. (2016), "Judgementoring and how to avert it: introducing ONSIDE Mentoring for beginning teachers", International Journal of Mentoring and Coaching in Education, $\quad$ Vol. 5 No.2,pp.87- 110. https://doi.org/10.1108/IJMCE-03-2016-0024

Supardi, A. Statistik. Bandung: Fakultas Tarbiyah IAIN Sunan Gunung Jati. 1997. 